\title{
IMPACTS OF WORKPLACE CULTURAL DIFFERENCES ON INNOVATION AND ECONOMIC GROWTH IN EUROPE
}

\author{
Kenneth Obinna Agu
}

\author{
PhD Student \\ Doctoral School of Management and Business Administration, Faculty of Economics and \\ Social Sciences, Szent Istvan University \\ E-mail: obinna.agu1@gmail.com
}

\begin{abstract}
Cultural differences and innovativeness are multi-faceted social phenomenon with innumerable manifestations. Majority of studies have indicated the positive impact of culture. There are some research findings which concluded that culture has a negative impact mainly due to language barriers of diverse cultural workforce which led to low level of communication, in turn led to low level of innovation. Hence the impact of culture on innovation and economic development is debated. Innovation takes place as an art of exercises routed into cultural view points and attitudes. With European Union struggling economies and financial crises, social integration and human capital mobility are key solutions to create innovation and innovative solutions. This study is, therefore aimed at examining the impacts of workplace cultural differences (in a form of human capital mobility) on innovation and economic growth in Europe. Accordingly, Germany, France, Belgium, and Luxembourg were purposively selected based on the higher number of diversified workforce available in companies located in these countries, in order words human capital mobility. Hence, data was collected using a questionnaire random sample of 392 employees (98 from each country) were selected. Consequently, though small portion of the respondents mentioned the negative impact of cultural diversity, the majority of the respondents and the results of the in-depth interview implied that cultural diversity brings people together and enables them to be creative and enhance their innovative performance. Mobility of skilled human capital is an attribute of culturally diverse workforce in a certain company which enable them to share knowledge and skills which in turn improve their innovative capacity. Therefore, this study concluded that cultural diversity has a significant positive impact on innovation and hence on the economic growth. But the barriers that may be seen at workplace due to cultural differences should be properly managed and prior training sessions to newly employed personnel and a platform where all the employees can get an opportunity to introduce themselves and ease their communication should be arranged.
\end{abstract}

Keywords: culture, innovation, mobility, economic growth, diversity

JEL classification: $000, J 24$

LCC: HM621-656, HD72-88

\section{Introduction}

Cultural diversity has an overall effect on how the organization operates. When considering the cultural differences and its influence on an organization, it is pertinent to know that it goes far as affecting the behavioural and thinking pattern of every employee within an organization. Hence, the culture of a person defines him, his action and way of thinking. National culture as a set of values and beliefs that guides how people select or evaluate actions, policies, events, or other people (Schwartz, 2012). 
National culture helps overcome the challenges that might arise in enforcing contracts, reducing transaction costs and other related costs across countries (Aggarwal and Goodell, 2009). Culture has an impact on economic activities in at least two ways. According to the model of Williamson (2000), culture indirectly affects the economic output which is also suggested by Licht et al. (2005). Williamson explained the correlation through analysis of culture, preferences or values and economic outcomes. These were tested by two variables "through the socialization process, by which it is maintained and transmitted, culture affects individual's values. This was distinguished between values that influence economic preferences (such as fertility or labour participation preferences) which can be thought of as parameters of a person's utility function. The other is political preferences (such as preferences for fiscal redistribution). Culture, thus, can affect economic outcomes though both these channels".

Compared with the extrapolated growth path between 1960-1973, when average growth was about five percent, today's GDP level is 75\% lower compared to its potential value. Such kind of figure would be barely believed a sufficient estimate of the output gap. Cultural and language barriers among employees increase the gap and communication costs; lower reliability of information and confidence and hence teamwork and social capital (Alesina \& La Ferrara, 2005). These facts may negatively affect many economic activities, and outputs, including innovation.

Multinational companies often rely on the international mobility of their employees (assigned expatriation) in order to transfer knowledge trans-nationally within their network of subsidiaries (Caligiuri and Bonache, 2016, Čeryová et al. 2020). Foreign emigrants can hence add better to the innovative practices of these companies. Its globally agreed that innovation plays a key role in economic development of a country. In addition to the research and development activity, the process of innovation is affected by tangible factors such as human capital and intangible environments where the innovation takes place.

Societal cultures such as shared values, beliefs and behaviours form the innovation environment. According to Williamson, the set of preferences economically relevant that can be affected by culture is potentially very large. This notion is proffer by Giuliano (2004), showed that living arrangements of US families are affected not only by economic situations, but also by cultural heritage. Another study on how cultural heritage impact work and fertility choices of American women was presented in Fernández Olivetti and Fogli (2004) and (2005) papers. In addition, Ichino and Maggi (2000) paper as per preferences for shirking on the job in Italy are mostly driven by a place of birth, which can be construed as a proxy for the cultural background. This was supported by The European Union and the neighbouring countries, although they are geographically close to each other, are quite different on the cultural background and environment. Hence, the innovative capacity of these countries depends on the above factors. According to Gorodnichenko and Roland (2011), culture is one of the most important attributes of economic development. Many social scientists have linked national cultures to innovation, however little emphasis was made to the regional integration of countries innovativeness.

With the presence of different views about the impact of culture on innovation, this study aims at analysing the impact of culture on innovation where innovation could play an important role in the economic development. Accordingly, four major European countries (Germany, France, Luxembourg and Belgium) with relatively diverse work force in their companies and the leaders of selected companies are considered to understand both the diverse workforces view towards the impact of culture on their innovativeness and economic development. 


\section{Materials and Methods}

\section{Sampling Methods, Sample Size and Analysis}

The paper draws its analysis from both theoretical and numerical scrutiny to evaluate outcome, conducted in form of questionnaires distributed to the people at different offices across different parts of Luxembourg, France, Germany and Belgium. The strategy is to gain a good understanding of the context of the research and the process that was enacted to analyse the theory appropriately. The big companies who have high number of diversified employees were purposively selected with multi-stage sampling techniques in order to meet the objectives of the research. First, only companies with more than 100 employees were purposively considered and selected from each country, with diverse employees. Then as many as the number of diverse employees are, allocation of time to filling the questionnaires is considered, therefore only 2 companies were selected from each country mentioned in the table below. Prior discussions with regards to the participation of the diverse employees were agreed, including the anonymity of the respondents. 392 questionnaires were distributed, collected and analysed to different categories of people in each selected company. The reason why these countries is selected is the high number of expatriates and cross border workers. Luxembourg and Belgium for example have many expatriates and cross border workers than any other EU countries. Furthermore, France, Belgium and German citizens are the main employees of Luxembourg companies. By sending the questionnaires to big Luxembourg companies, the paper is able to tap into diverse cultural environments of EU. This diverse cultural work force is essential for observation of the questionnaires. The research paper utilized such opportunity to reach out different people from different countries of the EU as this is the main aim.

Table 1.: Number of employees in companies of Luxembourg and Belgium

\begin{tabular}{|l|l|l|l|l|l|}
\hline & France & Germany & Belgium & Luxembourg & Total \\
\hline Number of employees & 98 & 98 & 98 & 98 & 392 \\
\hline
\end{tabular}

\section{Source: Own edition}

In order to determine the Sample size, the researcher took the simplified formula sample size determination formula suggested by Cochran's formula.

$$
n=\frac{N}{1+N e 2}
$$

Where $\mathrm{N}$ is the population size (of the eight companies employees surveyed) and e is the level of precision. Accordingly, for a $96 \%$ confidence level and e. $=0.04$, size of the sample we get the sample size as

$$
n=\frac{1050}{1+1050 * 0.04 * 0.04}=391.7 \approx 392
$$

And proportionally we selected the following number of respondents from each company.

This study is based on qualitative and quantitative research design on primary data collected through questionnaire and In-depth interview (both phone and face to face interview). Descriptive statistics has been used to present the questionnaire data. 


\section{Impact of innovation on growth}

Innovation enhances the capacity to utilize disposable assets and new technologies available. Authors such as Johnson et al, 2008 wrote that innovation is more complex than just invention, rather it involves transformation of knowledge into something new.

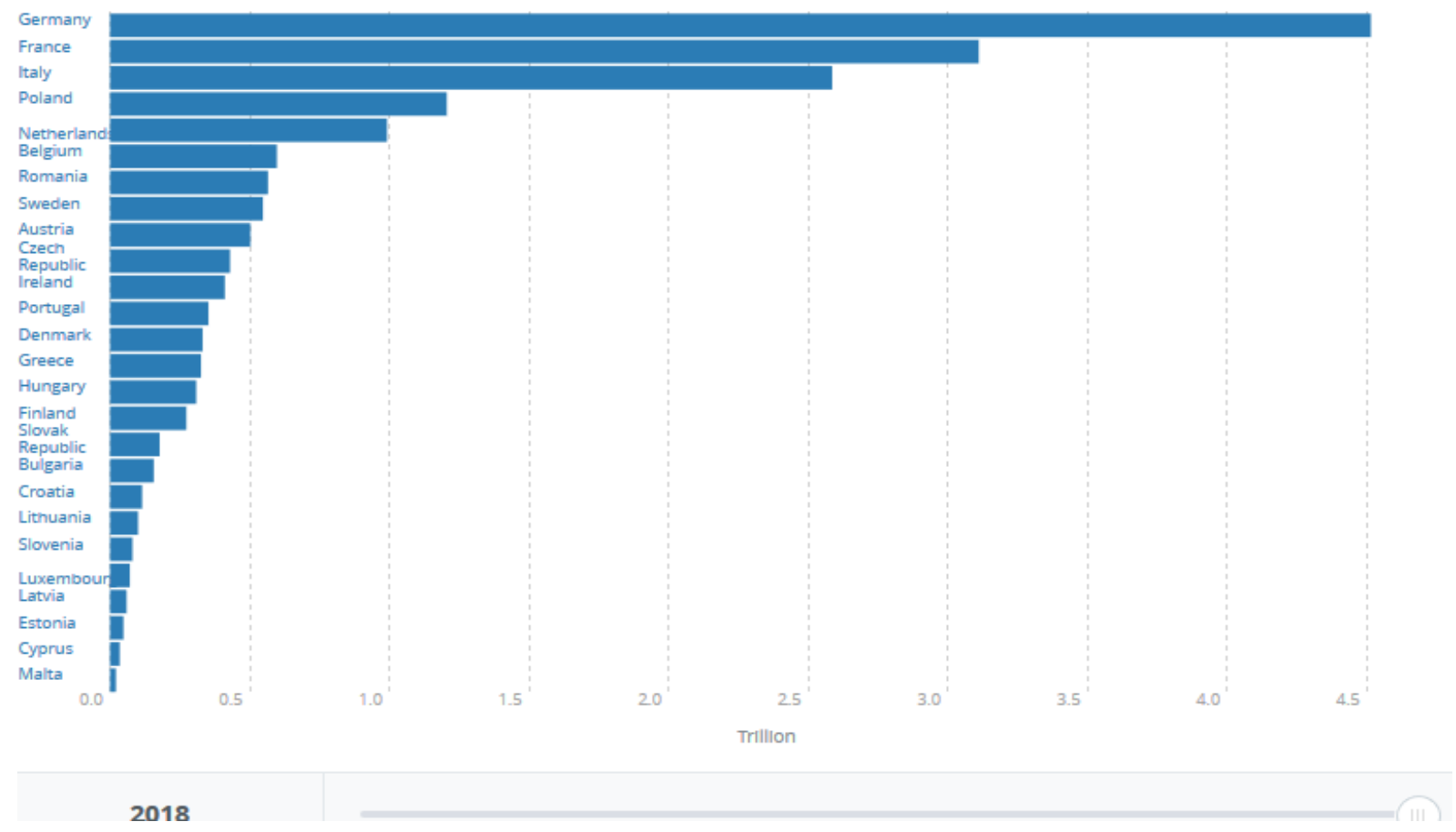

Figure 1.: GDP, PPP (current international \$) for European countries

\section{Source: World Bank}

The figure above shows that the disparity in Gross Domestic Product (GDP) in the European Countries where only a few countries have a higher GDP while the majority are low indicating the disparity in the economic development and hence innovative capacity and the actual "level" of innovation might differ significantly.

By innovativeness, we mean knowledge-based transformation that outcomes to creativity. The innovation output gaps and disparities between the European territories are most frequently attributed to differences in inputs to innovation production. The amount and quality of inputs and the innovative infrastructure are a key player in the EU innovation capacity and they are a reflection of cultural and institutional capacity. In principle, exploring into the difference structures across EU territories, one could pin-point components such as 'Fundamental Features' that makes a region more 'innovation prone' and as such, much richer and more attractive to investments and innovativeness than other territories. These structural characteristics could include: education / life-long learning / sectoral composition / use of resources / demographics / infrastructural inputs / access to investments and finance / interconnectedness and transportation modals and above all, the political and economic dispensation and dissemination capabilities, which could affect mainly income, GDP and GDP per capita, employment and skills and amongst other things are quite very important.

Innovation is a key player in achieving sustainable economic growth of developed and emerging countries (OECD, 2010; Thompson, 2015) and it is recognized as a key base of effectiveness (González-Pernía et al., 2012; Rumen, 2008; Şener and Sarıdoğan, 2011). 
Successful innovation leads to higher economic performance and creates social and human capital, culture, and environmental advantages (Dakhli and de Clercq, 2004; OECD, 2007).

As competition across products and services becomes more and more the primary focus for firms, the search for innovation becomes crucial. The competition has come a long way to create worldwide scale and hereby increasing the competitive pressures within companies. Innovation signifies the ability of an organization to utilize disposable resources and new technologies to be successful.

Innovation has a great impact on a socio-economic development of a country. Innovation has a great role on an economic development performance (Freeman, 1990). According to the financial management theory, mainly on the arbitrage pricing theory an alternative view of risk and return by Ross et al., (2008) the statement on innovation and growth discussed on how to construct portfolios and to evaluate their returns.

\section{Determinants of Innovation}

In this study, culture and human capital are taken into consideration as most important determinants innovation.

\section{Culture}

Several studies consider culture as a national trait that can explain cross-country differences in corporate practices (e.g., Bryan et al., 2015; El Ghoul and Zheng, 2016; Zheng et al., 2012), or focus on cultural differences and how they affect financial outcomes (e.g., Ahern et al., 2015; Beugelsdijk and Frijns, 2010; Karolyi, 2016). According Zemke et al, (2013), people, organizational identity and social identities has a link and high influence on how people respond to situations around them.

Literatures in the management area considers culture as a "double-edged sword" (Milliken and Martins, 1996), identifying both positive and negative aspects of cultural diversity. On the positive side, cultural diversity engenders information elaboration, offering a diverse range of knowledge and perspectives (Nederveen Pieterse et al., 2013). In addition, foreign nationals can bring in specific knowledge of their home countries, which may benefit the firm if it has operations in that market (Maznevski, 1994). This view of cultural diversity could clarify, for example, the findings of Masulis et al. (2012) who explain that companies with foreign independent directors make better cross-border gains when the goals are from their home country. On the negative side, cultural diversity imposes frictions. Research from Doney et al., 1998, concluded that cultural diversified group creates difficulty in management, weaken communication potential and frequently becomes a source of confusion and misunderstanding. Similarly, Bjørnskov (2008) opines that cultural diversity can contribute to low intragroup trust. Such negative features of cultural diversity are also consistent with findings of Ahern et al. (2015), who postulate that cultural distance between an acquiring firm and its target diminish the chances of a successful acquisition.

Some explanation for the positive effect of immigration on innovation is related to the impact of cultural and ethnic diversity on innovation. Ethnic diversity is typically used as a surrogate of cultural diversity and evaluated at the different levels. Diversity at the firm level enhances innovation because it broadens the firm's knowledge base, allows for new knowledge combinations, enhancing problem solving and the generation of new ideas (Østergaard et al., 2011; Parrotta et al., 2014; Kemeny, 2017). At the identical time diversity can create barriers 
to interaction and communication and result in conflicts and lack of common action. If competences and experiences are extremely disconnected, innovative learning is additionally tougher. Existing studies have shown that ethnic diversity, measured at the regional level, enhances positive externalities supported on cultural diversity and creativity (Niebuhr, 2010; Nathan and Lee, 2013; Nathan, 2015), also as complementarities with in the labour market conditions and demand (Ottaviano and Peri, 2012). A number of papers have also examined the role of diversity in a European framework with combined results (Niebuhr, 2010; Ozgen et al., 2012; Bratti and Conti, 2018).

Having homogeneous workforce in a company became very difficult due the globalization and competition. Today's labour force is becoming more and more heterogeneous: aging, migration, women's increased labour participation, and technological change are key drivers of this phenomenon. In addition, there is increased legislative pressure in many countries for companies to variegate their workforce through either quotas or affirmative action. Consequently, workforce diversity is increasingly becoming an essential business concern.

Workplace diversity should be managed both internally (among the leadership and employees) and externally by identifying and meeting the customer needs.

As heterogeneity compose of different cultural background - mainly having different cultural backgrounds and motivational values tend to vary by national culture for example, with Eastern nations endorsing more collectivism and Western nations endorsing more individualism (Hofstede, 1980; Schwartz, 1992).

\section{Human Capital Mobility}

The past centuries are characterized with low income, short life and poor economic growth. This time, people have relatively healthier, longer, richer and optimistically better off lives. The current globalization effect has affected the level of knowledge and its dissemination, the educational and other training levels and health facilities have grown up and hence migration became higher affecting the demographic characteristics by fertility change.

According to, Human capital was defined Oxford English Dictionary as refers to "the abilities the workforce owns and is considered as a resource". It encompasses the idea of investments in health, education and training to increase an individual's productivity.

As one of most important factors of innovation, the general level of human capital of a country: knowledge, skills and abilities of the labour force that can be improved with education - is commonly supposed to positively influence innovation. A synopsis of theoretical arguments and empirical findings can be found in Snell, Subramaniam and Youndt (2004), and Dakhli and De Clercq (2004). The quality of labour force depends on the level of human capital employed or available in R\&D. Educated and skilled employees tend to be more creative, and knowledgeable which makes them interrogate procedures.

The impact of immigration hosting country in terms of wages and employment opportunities, productivity of companies, and development of trade have been a key area of interest for economic researchers. In recent years, researcher have also been focusing on impacts of immigration on innovation which indeed is a key factor of development. Ozgen, Nijkamp, and Poot (2013) have summarized how immigration can affect the innovation and economic growth. 
There are several traditional sectors with high number of cheap and low level of education (Card \&Lewis, 2007; De Arcangelis, Di Porto, \& Santoni, 2015), with negative effects on innovation. An abundant low-skilled labour force may reduce firms' incentives to invest in skill-intensive production technologies, hampering innovation and physical capital investment (Lewis, 2011; Peri, 2012).

The use of NUTS-2 in European regions by Ozgen, Nijkamp, and Poot (2012), to estimate the effects of the share of immigrants by continent of origin on innovation shows some heterogeneity. However, this can only be indirectly related to the skill levels of immigrants. Elsewhere, Jahn and Steinhardt (2016) adopted quasi-experimental evidence in exploiting a placement policy for ethnic German immigrants (Aussiedler). Despite the majority of inflows being unskilled, no negative (or evena positive) impact on innovation is found. This is explained by the authors in terms of the positive effects of skilled migrants outweighing those of the low-skilled migrants and of the small cultural and language differences of ethnic Germans - compared with the average migrant - who were legally treated as German citizens from their arrival. De Arcangelis et al., (2015), found that there was insignificant influence of immigrants on the economic structural composition in Italy.

According to the resource-based perspective, a company can enhance its economic advantage by acquiring resources that are important, unique, and inimitable. Organizational actions are continually built on human resources and expertise. Irrespective of a company's size of equipment or factory building, if it wants to win in a competitive environment, the company has to rely on superb creation technology, research and development competencies, creative marketing, and leaders with visions to move the company forward. It, is therefore, possible to consider human capital as main assets of a corporation.

Human capital theory, which originated from the field of economics, is generally defined as the knowledge, experience, and skills that individuals develop through education and training (Becker 1964, Lajdová et al. 1996). Human capital theory indicates that educational level and job experience are positively related to personal income. Human capital leads to improved problem-solving abilities, the capacity for learning, and the potential to make better decisions. Moreover, human capital can increase the quality and consistency of the delivered work and is beneficial for the acquisition of external resources (e.g., information, market opportunity, relationship).

Value and personality are relatively stable personal characteristics. Once an individual uncovers that an organization corresponds with his or her personal values, he or she may remain to work for the organization, even if the compensation is lower than the favoured amount (Wei, 2018).

Innovation is a skill of possession of inner abilities/human capital as accumulation of knowledge and skills, lifestyles, societal and individuality characteristics, including inventiveness to produce economic value. Apart from that, human capital can also be considered as talents, skills, intelligence, judgement, wisdom, experiences, abilities, training, knowledge and resources possessed individually and collectively by a population. These resources represent the total capacity of the people which can be utilized to attain goals of the state or nation.

Effects of cluster of skills led opportunities - basically mobility of skills across territories in order to learn and share know-hows. We labelled the primary goals of cultural differences as economic benefits, basically knowledge production function, measured as a coefficient of clustered skills to achieve innovativeness and creativity. These clusters are possible through 
human capital mobility that synchronizes different cultural properties, in order words, migration of highly skilled individuals. Migration would present the capacity to assimilate and transform inter-regional knowledge spillovers into innovation. Individuals of different national cultural properties interacts together in form of work and or education relationships, these interactions create multi-functional effects to different spectrum of territorial economics, social and political environments to achieve creativity (Agu \& Fekete Farkas, 2016).

Using individual data on workers in Science \& Engineering (S\&E) in the United States, a set of studies indicates that the overall inventiveness increases through the direct roles of immigrant inventors (Kerr and Lincoln, 2010; Hunt, Gauthier-Loiselle, 2010; No and Walsh, 2010). A combination of immigration policies and selection process in the US have made immigrants averagely more educated than natives (Batalova and Fix, 2017), have higher chances to work in S\&E occupations and probably have higher entrepreneurial and inventive abilities (Hunt, Gauthier-Loiselle, 2010).

Another set of explanations focus on the impact of ethnic diversity on innovation (e.g. Ottaviano and Peri, 2012; Østergaard et al., 2011; Ozgen et al., 2012; Nathan and Lee, 2013; Parrotta et al., 2014; Nathan, 2015). Evidence indicates that companies with an ethnically diverse workforce seem to be more innovative (Parrotta et al., 2014). Diversity at the firm level enhances innovation because diverse immigrants provide complementary skills to natives, enhance critical mass and specialization of tasks within the firm and favour knowledge spillovers. At the regional level, ethnic diversity improves positive externalities based on cultural diversity and creativity, as well as complementarities within labour market conditions. Some studies such as (Ozgen et al., 2012 and 2017; Niebuhr, 2010; Nathan and Lee, 2013) have analysed the impact of ethnic diversity on innovation at a regional level and found mixed results The role of externalities created by a diverse environment, which favour complementarity and induce creativity and problem solving (e.g. Niebuhr, 2010; Nathan and Lee, 2013; Nathan, 2015).

A growing number of papers have recently studied whether high skilled migration stimulates innovation activities in destination countries (Kerr, 2016; Lissoni, 2018). Typically, two sets of explanations are put forward. The first one argues that skilled migration contributes directly to research activities and innovation, the second one underlines the role of ethnic and cultural diversity.

The first explanation is mainly based on the literature that analyses the US experience, where in 2015 the share of tertiary educated migrants was $48 \%$ and, at the same time, $30 \%$ among the US-born population (Batalova and Fix, 2017). In addition, skilled migrants are more likely to work in S\&E occupations and display higher entrepreneurial and inventive abilities (Chellaraj et al., 2008; Kerr and Kerr, 2016).

While the US evidence speaks largely in favour of a direct positive effect of skilled immigration on innovation activities, in Europe the recent literature shows more mixed results. Various papers found that skilled migrants positively contribute to the number of patents and citations in scientific publications in European countries (Bosetti et al., 2015; Gagliardi, 2015), but other studies suggest that this might not always be the case (Ozgen et al., 2012; Bratti and Conti, 2018; Zheng and Ejermo, 2015). This could be due to the different nature of skilled immigration in Europe. As shown by Kerr et al. (2016), the distribution of skilled migrants in OECD host countries is very uneven, with the US economy hosting almost half of all the skilled immigrants. 


\section{Results}

Table 2 below show the gender share of participants of the survey. Accordingly, about $70 \%$ of the randomly selected participants of the survey from national and multi-national companies in Germany, 63.33\% from France, 54.44\% from Luxembourg and 47.78\% from Belgium were males while the remaining $30 \%, 26.67 \%, 41.56 \%$ and $52.22 \%$ were female participants from Germany, France, Luxembourg and Belgium respectively.

Table 2.: survey participants by Gender

\begin{tabular}{cccc}
\hline Country & Gender & Frequency & Percentage \\
\hline \multirow{2}{*}{ Germany } & Male & 63 & $\mathbf{7 0} \%$ \\
\cline { 2 - 4 } & Female & 27 & $\mathbf{3 0 \%}$ \\
\hline \multirow{2}{*}{ France } & Gender & Frequency & Percentage \\
& Male & 57 & $\mathbf{6 3 . 3 3 \%}$ \\
\cline { 2 - 4 } & Female & 33 & $\mathbf{2 6 . 6 7 \%}$ \\
\hline \multirow{2}{*}{ Luxembourg } & Gender & Frequency & Percentage \\
& Male & 49 & $\mathbf{5 4 . 4 4}$ \\
\hline & Female & 41 & $\mathbf{4 1 . 5 6 \%}$ \\
\hline Belgium & Gender & Frequency & Percentage \\
& Male & 43 & $\mathbf{4 7 . 7 8 \%}$ \\
\hline & Female & 47 & $\mathbf{5 2 . 2 2 \%}$ \\
\hline
\end{tabular}

Source: Own Work based on R Studio Results

As it is well known that a lot of racial diverse people lives in the study areas, for example, Europeans, Black Africans, Asians and Latin Americans and others. Majority of the employed and participated people in the survey were White Europeans in both Luxembourg and Belgium followed by Black Africans, Asians, and Latin Americans, respectively.

The table 3 below shows that the composition of survey participants based on their ethnic group. As it can be seen below from table 2, almost major ethnic groups across the globe are included in the survey. These enable the study to be inclusive and unbiased in terms of result generalization.

Table 3: Frequency and percentage of race of respondents

\begin{tabular}{|l|l|l|l|l|l|l|l|l|}
\hline \multirow{2}{*}{ Race } & \multicolumn{2}{l|}{ Germany } & \multicolumn{2}{l|}{ France } & \multicolumn{2}{l|}{ Luxembourg } & \multicolumn{2}{l|}{ Belgium } \\
\cline { 2 - 9 } & Freq. & Perc. & Freq. & Perc. & Freq. & Perc. & Freq. & Perc. \\
\hline $\begin{array}{l}\text { White } \\
\text { European }\end{array}$ & 27 & $30 \%$ & 22 & $24.45 \%$ & 24 & $26.27 \%$ & 29 & $32.22 \%$ \\
\hline $\begin{array}{l}\text { Black } \\
\text { African }\end{array}$ & 21 & $23.33 \%$ & 31 & $34.44 \%$ & 22 & $24.45 \%$ & 26 & $28.89 \%$ \\
\hline Asian & 19 & $21.11 \%$ & 10 & $11.11 \%$ & 19 & $21.11 \%$ & 21 & $23.33 \%$ \\
\hline $\begin{array}{l}\text { Latin } \\
\text { American }\end{array}$ & 15 & $16.67 \%$ & 15 & $16.67 \%$ & 20 & $22.22 \%$ & 10 & $11.11 \%$ \\
\hline Others & 8 & $8.89 \%$ & 12 & $13.33 \%$ & 5 & 5.56 & 4 & $4.45 \%$ \\
\hline
\end{tabular}

Source: Own Work based on R Studio Results

All the respondents came with common sense that diversity have never been a problem for their performance in their respective jobs. Moreover, they believe that cultural diversity brings 
people together and enables them to be creative and enhance their innovative performance. As they work to achieve common goal, most respondents have got a good experience from the diversity and it let them identify their weaknesses and strengths. The response from the data to how the cultural diversity can lead to innovation shows that it impacts innovation through culture, clear objective and through management. These diverse identities and other major variables have impacts on the working environment of a company and hence enhance the innovativeness and creativity of the employees.

The organization incorporating more ethnic groups leads to the prosper of the organizations concerning production due to sharing of knowledge and issues of marketing. Innovation is mainly brought through by setting a clear objective and better management and culture has the most important role to play in fostering innovation. The effect of academic qualification is one of the important factors that determine the level of creativity, innovation, and cultural integration. The higher the academic rank, the greater creativity and innovativeness. In this situation, it can be concluded that as the number of years I workforce and academic rank as the same time grow, there will likely have high skill of innovation.

The results of survey indicate that the impact of culture two folded. These two-folded views are in line with Milliken and Martins (1996). Some of the respondents (12\%) indicates that cultural difference negatively affects the ability to innovate. With the presence of different cultural norms across the globe which impact the individual personality and attitude towards creativity, the respondents mentioned the language barrier, gap in communicating ability among employees of their organization are the main hindering factors to innovation capacity. This discovery is in line with the findings of previous research such as Doney et al., (1998), Bjørnskov (2008), and Ahern et al., (2015). On the other hand, the larger portion of the respondents, $88 \%$, are in favour of cultural diversity in terms of religion, tradition, ethnicity, academic qualification. They believe that the diversity in culture enable them share traditional indigenous knowledge and skills acquired in the childhood and educational career, leadership management of the worker. These finding is also like the findings of Nederveen Pieterse et al., (2013), Masulis et al., (2012) and Maznevski, (1994). Since culturally diversified employees can only be engaged in a company with the possibility of migration, all respondent from these different countries replied that skilled labour migration is an important way of getting culturally different employees.

The in-depth interview mainly focused on the managers perception towards the impact of culture on innovation and the role that the cultural diversity plays in the development of their respective companies and the nation as well. Accordingly, the interview results show that majority of the leaders of the company are in favour of cultural diversity with proper skills. At some point, there are some companies who hire low skilled labours which affects the innovative capacity negatively. When asked about reginal integration through mobility, they propose that European countries should allow regional mobility to improve the innovative skills and share knowledge between the employees. Moreover, they believed that not only low-level employers, but also the board members mix should culturally diversified. Economically, innovation enables a company to secure sustainable competitive advantage and adapt and act successfully in the changing condition. Moreover, the interviews explain that innovation allow company to develop new markets and new customers and reduce costs while increasing efficiency. Closing gaps and increasing cultural and strategic partnership is expected to enhance the performance of companies. Successful companies are well-known for their strategy in composing/teamingup culturally diversified and talented, skilled workforce and devising a conducive structure 


\section{Conclusion and Recommendation}

This study mainly focused on analysing the impact of culture on innovation, the impact of innovation on economic growth, and impacts of human capital mobility on both innovation and economic growth. The study surveyed two big companies with more than 100 employees in four European countries with relatively high culturally diversified workers and the countries are also at different level of economic growth as per their GDP based on World Bank data.

Hence, this study concluded that though small portion of the respondents mentioned the negative impact of cultural diversity, the majority of the respondents and the results of in-depth interview implied that cultural diversity brings people together and enables them to be creative and enhance their innovative performance. As they work to achieve common goal, most respondents have got a good experience from the diversity and it let them identify their weaknesses and strengths. Moreover, Mobility of skilled human capital is an attribute to culturally diverse workforce in certain companies which enable them share knowledge and skills which in turn help their innovative capacity.

Innovation in a business requires the creation of considerable new values for customers and company by developing strategic dimensions, choices, and directions of the entire business system. A combination of various strategies, development of new products and services, target of new markets through well designed innovative management will empower company's value chain to help achieve their growth ambitions. Organizational innovativeness could be seen as the deliberate use of procedures, products, processes and ideas inside a group or organization to the intended unit of adoption which is supposed to be significantly beneficial for the person, the group, organization or wider society in general. The culture of the organization is very crucial as it is a set of shared value that support organizational members to understand the organizational functions, guides their thinking and behaviour in the organization to achieve innovative solutions.

Therefore, this study concluded that cultural diversity has a significant positive impact on innovation and hence on the economic growth. But the barriers that may be seen at workplace due to cultural difference should properly managed and prior training sessions to newly employed ones and a platform where all the employees can get an opportunity to introduce themselves and ease their communication should be arranged.

\section{References}

1. Aggarwal, R., Goodell, J.W., (2009): Markets and institutions in financial intermediation: national characteristics as determinants. Journal of Banking and Finance 33, 1770-1780. https://doi.org/10.1016/j.jbankfin.2009.03.004

2. Agu Kenneth O., Maria Fekete F., (2016): Creativity and Innovation Exploration: The Impact of Cultural Diversity in an Organization: Management Journal of Management 2016, No. 2 (23) ISSN 1648 - 7974 (VAGYDA)

3. Ahern, K., Daminelli, D., Fracassi, C., (2015): Lost in translation? The effect of cultural values on mergers around the world. J. Financ. Econ. 117, 165-189. https://doi.org/10.1016/j.jfineco.2012.08.006

4. Alesina, A., \& La Ferrara, E. (2005): Ethnic diversity and economic performance. Journal of Economic Literature, 43, 762-800. doi:10. 1257/002205105774431243

5. Anderson, R.C., Reeb, D.M., Upadhyay, A., Zhao, W., (2011): The economics of director heterogeneity. Financ. Manag. 40, 5-38. https://doi.org/10.1111/j.1755053X.2010.01133.x 
6. Becker G (1964): Human capital: a theoretical analysis with special reference to education. Columbia University Press, New York and economic growth. Procedia Social and Behavioral Sciences, 24, 815-828. ISBN: 0-226-04119-0

7. Batalova, J., Fix, M., (2017): New Brain Gain: Rising Human Capital Among Recent Immigrants to the United States. Migration Policy Institute, Facts Sheet June, Washington DC

8. Beugelsdijk, S., Frijns, B., (2010): A cultural explanation of the foreign bias in international asset allocation. Journal of Banking and Finance 34, 2121-2131. https://doi.org/10.1016/j.jbankfin.2010.01.020

9. Bjørnskov, C., (2008): Social trust and fractionalization: a possible reinterpretation. Eur. Social. Rev. 24, 271-283. https://doi.org/10.1093/esr/jen004

10. Bosetti, V., Cattaneo, C., \& Verdolini, E. (2015): Migration of skilled workers and innovation: A European perspective. Journal of International Economics, 96, 311-322. http://doi:10.1016/j.jinteco.2015.04.002

11. Bratti, M., Conti, C., 2018. The effect of immigration on innovation in Italy. Reg. Stud. 52(7), 934-947. https://doi.org/10.1080/00343404.2017.1360483

12. Bryan, S.H., Nash, R.C., Patel, A., (2015): The effect of cultural distance on contracting decisions: the case of executive compensation. J. Corp. Finance. 33, 180195. http://doi.10.1016/j.jcorpfin.2015.06.001

13. Caligiuri, P., Bonache, J., (2016): Evolving and enduring challenges in global mobility. J. World Bus. 51 (1), 127-141. http://DOI.10.1016/j.jwb.2015.10.001

14. Card, D., \& Lewis, E. (2007): The diffusion of Mexican immigrants during the 1990s: Explanations and impacts. In G. J. Borjas (Ed.), Mexican immigration to the United States (pp. 193-227). Chicago: University of Chicago Press.

15. Chellaraj, G., Maskus, K., Mattoo, A., (2008): The contribution of skilled immigrations and international graduate students to U.S. Innovation. Rev. Int. Econ. 16 (3), 444-462. https://doi.org/10.1111/j.1467-9396.2007.00714.x

16. Čeryová, D. -- Bullová, T. -- Turčeková, N. -- Aamičková, I. -- Moravčíková, D. -Bielik, P. (2020): Assessment of the Renewable Energy Sector Performance Using Selected Indicators in European Union Countries. In Resources. 9, 102 (2020), s. 2020. ISSN 2079-9276.

17. Čeryová, D. -- Bullová T. -- Adamičková, I. -- Turčeková, N. -- Bielik, P. (2020): Potential of investments into renewable energy sources. In: Problems and Perspectives in Management. 18, 2 (2020), s. 57--63. ISSN 1727-7051.

18. Dakhli, M and D de Clercq (2004): Human capital, social capital, and innovation: A multi-country study. Entrepreneurship and Regional Development, 16, 107-128. https://doi.org/10.1080/08985620410001677835

19. De Arcangelis, G., Di Porto, E., \& Santoni, G. (2015): Migration, labour tasks and production structure. Regional Science and Urban Economics, 53, 156-169. doi: 10.1016/j.regsciurbeco. 2015.06.001

20. Doney, P.M., Cannon, J.P., Mullen, M.R., (1998): Understanding the influence of national culture on the development of trust. Acad. Manag. Rev. 23, 601-620. Econ. J. Macroecon. 2 (2), 31-56. https://doi.org/10.5465/amr.1998.926629

21. El Ghoul, S., Zheng, X., (2016): Trade credit provision and national culture. J. Corp. Financ. 41, 475-501.

22. For Europe (UN-ECE), United Nations. http://DOI.10.1016/j.jcorpfin.2016.07.002

23. Fernández, R., A. Fogli, and C. Olivetti, (2004): Mothers and Sons: Preference Formation and Female Labour Force Dynamics, Quarterly Journal of Economics, 119(4), 1249-1299. 
24. Fernández Raquel and Alessandra Fogli, (2005): Culture: An Empirical Investigation of Beliefs, Work, and Fertility, NBER WP 11268.

25. Freeman, C., (1990): The economics of innovation. Elgar Reference Collection, Cheltenham: Edward Elgar.

26. Gagliardi, L., (2015): Does skilled migration foster innovative performance? Evidence from British local areas. Papers in Regional Science 94 (4), 773-794. https://doi.org/10.1111/pirs.12095

27. Giuliano, Paola, (2004): On the Determinants of Living Arrangements in Western Europe: Does Cultural Origin Matter? Working paper.

28. González-Pernía, JL, I Peña-Legazkue and F Vendrell-Herrero (2012): Innovation, entrepreneurial activity and competitiveness at a sub-national level. Small Business Economics, 39, 561-574. https://doi.org/10.1007/s11187-011-9330-y

29. Gorodnichenko, Y and G Roland (2011): Individualism, innovation and long-run growth. PNAS, 108 (Supplement 4), 21316-21319. https://doi.org/10.1073/pnas.1101933108

30. Hofstede, G (1980): Culture's Consequences: International Differences in WorkRelated Value. Beverly Hills, CA: Sage Publications. https://doi.org/10.1002/job.4030030208

31. Hunt, Jennifer, and Marjolaine Gauthier-Loiselle (2010): "How Much Does Immigration Boost Innovation?" American Economic Journal: Macroeconomics, 2 (2): 31-56. http:/DOI.10.1257/mac.2.2.31

32. Ichino and Maggi, (2000): Work Environment and Individual Background: Explaining Regional Shirking Differentials in a Large Italian Firm, Quarterly Journal of Economics, 115(3): 1057-1090

33. Jahn, V., \& Steinhardt, M. F. (2016): Innovation and immigration - Insights from a placement policy. Economics Letters, 146, 116-119. http//doi: 10.1016/j.econlet.2016.07.033

34. Johnson, G. Kevan S., and Richard W. (2008): Exploring Corporate Strategy. England: Pearson Education Limited. 8th Ed. ISBN-13: 978-0273711919 ISBN-10: 0273711911

35. Karolyi, A., (2016): The gravity of culture for finance. J. Corp. Financ. 41, 610-625. http://doi.10.1016/j.jcorpfin.2016.07.003

36. Kemeny, T., (2017): Immigrant diversity and economic performance in cities. Int. Reg. Sci. Rev. 40 (2), 164-208. https://doi.org/10.1177/0160017614541695

37. Kerr, S.P., Kerr, W.R., (2016): Immigrants play a disproportionate role in American entrepreneurship. Harv. Bus. https://hbr.org/2016/10/immigrants-play-adisproportionate-role-in-american-entrepreneurship

38. Kerr, S.P., Kerr, W.R., Özden, C., Parsons, C., (2016): Global talent flows. J. Econ. Perspect. 30 (4), 83-106. http://DOI.10.1257/jep.30.4.83

39. Kerr, W., Lincon, W.F., (2010): The supply side of innovation: H-1B visa reforms and U.S. Ethnic invention. Journal of Labour Economics 28 (3), 473-508. http://dx.doi.org/10.1086/651934

40. Kerr, W.R., (2016): US high-skilled immigration, innovation, and entrepreneurship: empirical approaches and evidence. In: Fink, C., Miguelez, E. (Eds.), The International Mobility of Talent and Innovation: New Evidence and Policy Implications. Cambridge University Press, Cambridge, pp. 193-221. http://nrs.harvard.edu/urn3:HUL.InstRepos:11508211

41. Lajdová, Z. -- Lajda, J. -- Kapusta, J. - Bielik, P. (2016): Consequences of maize cultivation intended for biogas production. In: Agricultural economics. 62, 12 (2016), s. 543--549. 
42. Lewis, E. (2011): Immigration, skill mix, and capital skill complementarity. Quarterly Journal of Economics, 126, 1029-1069. http://doi:10.1093/qje/qjr011

43. Licht, A.N., Goldschmidt, C., Schwartz, S.H., (2005): Culture, law, and corporate governance. International Review of Law and Economics 25, 229-255. https://doi.org/10.1016/j.irle.2005.06.005

44. Lissoni, F., (2018): International migration and innovation diffusion: an eclectic survey. Reg. Stud. 52 (5), 702-714. https://doi.org/10.1080/00343404.2017.1346370

45. Masulis, R.W.,Wang, C., Xie, F., (2012): Globalizing the boardroom- the effects of foreign directors on corporate governance and firm performance. J. Account. Econ. 53,527-554. http://doi.10.1016/j.jacceco.2011.12.003

46. Maznevski, M.L., (1994): Understanding our differences: performance in decisionmaking groups with diverse members. Hum. Relat. 47, 531-552. https://doi.org/10.1177/001872679404700504

47. Milliken, F.J., Martins, L.L., (1996): Searching for common threads: understanding the multiple effects of diversity in organizational groups. Acad. Manag. Rev. 21,402433. https://doi.org/10.5465/amr.1996.9605060217

48. Nathan, M., (2015): Same difference? Minority ethnic inventors, diversity and innovation in the UK. J. Econ. Geogr. 15, 129-168. https://doi.org/10.1093/jeg/lbu006

49. Nathan, M., Lee, N., (2013): Cultural diversity, innovation, and entrepreneurship: firm level evidence from London. Econ. Geogr. 89 (4), 367-394. https://doi.org/10.1111/ecge.12016

50. Nederveen Pieterse, A., van Knippenberg, D., van Diererdonck, D., (2013): Cultural diversity and team performance: the role of team member goal orientation. Acad. Manag. J. 56, 782-804. http://doi.10.5465/amj.2010.0992

51. Niebuhr, A., (2010): Migration and innovation. Does Cultural Diversity matter for regional R\&D Activity? Papers in Regional Sciences 89 (3), 563-585. https://doi.org/10.1111/j.1435-5957.2009.00271.x

52. No, Y., Walsh, J.P., (2010): The importance of foreign-born talent for US innovation. Nat. Biotechnol. 28 (3), 289-291. http://DOI.10.1038/nbt0310-289

53. OECD (2007): Innovation and Growth: Rationale for an Innovation Strategy. Paris: OECD https://www.oecd.org/sti/theoecdinnovationstrategyfurtherinformation.htm

54. OECD (2010): Ministerial Report on the OECD Innovation Strategy. Paris: OECD Publishing. https://www.oecd.org/sti/45326349.pdf

55. Østergaard, C.R., Timmermans, B., Kristinsson, K., (2011): Does a different view create something new? The effect of employee diversity on innovation. Res. Policy 40 (3),500-509 04.2011. http://dx.doi.10.1016./j.respol.2010.11.004

56. Ottaviano, G.M., Peri, G., (2012): Rethinking the effects of immigration on wages. J. Eur. Econ. Assoc. 10 (1), 152-197. http://DOI.j.1542-4774.2011.01052.x

57. Ozgen, C., Nijkamp, P., \& Poot, J. (2013): The impact of cultural diversity on firm innovation: Evidence from Dutch micro-data. IZA Journal of Migration, 2, 18. doi:10.1186/2193-9039-2-18

58. Ozgen, C., Nijkamp, P., Poot, J., (2012): Immigration and innovation in European regions. In: Nijkamp, P., Poot, J., Sahin, M. (Eds.), Migration Impact Assessment: New Horizons. Edward Elgar. ISBN -13: 978-0-444-53768-3

59. Ozgen, C., Nijkamp, P., Poot, J., (2017): The elusive effects of workplace diversity on innovation. Papers in Regional Science 96, S29-S49. https://doi.org/10.1111/pirs. 12176. 
60. Parrotta, P., Pozzoli, D., Pytlikova, M., (2014): The Nexus Between labour diversity and firm's innovation. J. Popul. Econ. 27 (303). https://doi.org/10.1007/s00148-0130491-7.

61. Peri, G. (2012): The effect of immigration on productivity: Evidence from U.S. states. Review of Economics and Statistics, 94, 348-358.doi:10.1162/REST_a_00137

62. ROSS, A. S., \& WESTERFIELD, W. R., (2008): Modern Financial Management. 8th Ed. McGraw-Hill Irwin International Edition. U.S.A. ISBN-10: 0071286527 ISBN13: $978-0071286527$

63. Rumen, D (2008): Innovation as a Key Driver of Competitiveness, Economic Commission

http://www.unece.org/fileadmin/DAM/oes/nutshel1/2008/6_Innovation_Key_Driver. pdf.

64. Schwartz, S.H., 2012. An overview of the Schwartz theory of basic values. Online Read. Psychol. Cult. 2 (1). http://dx.doi.org/10.9707/2307-0919.1116

65. Schwartz, SH (1992): Universals in the content and structure of values: Theoretical advances and empirical tests in 20 countries. In Advances in Experimental Social Psychology. MP Zanna (ed.), San Diego, CA: Academic Press. http://doi:10.1016/S0065-2601(08)60281-6

66. Şener, S and E Sarıdoğan (2011): The effects of science-technology-innovation on competitiveness. http://doi:10.1016/j.sbspro.2011.09.127

67. Thompson, M (2015): Social capital, innovation and economic growth. Working Paper NIPE WP 3. http://DOI.10.1016/j.socec.2018.01.005

68. Wei, Y.-C. (2018): Human Capital Mobility: Tie and Fit. https://doi.org/10.1007/978981-10-7772-2 3

69. Williamson, O.E., (2000): The new institutional economics: taking stock, looking ahead. Journal of Economic Literature 38, 595-613. http://DOI.10.1257/jel.38.3.595

70. Youndt, M.A., Subramaniam, M. \& Snell, S.A., (2004): Intellectual Capital Profiles: An Examination of Investment and Return. Journal of Management Studies, 41, 335361., https://doi.org/10.1111/j.1467-6486.2004.00435.x

71. Zemke, R., Raines, C., \& Filipczak, B., (2013): Generations at work: managing the clash of boomers, Gen Xers, and Gen Yers in the workplace. 2nd ed. New York: American Management Association.

72. Zheng, X., El Ghoul, S., Guedhami, O., Kwok, C.C.Y., (2012): National culture and corporate debt maturity. J. Bank. Financ. 36, 468-488. http://doi.10.1016/j.jbankfin.2011.08.004

73. Zheng, Y., Ejermo, O., (S2015): How do the foreign-born perform in inventive activity? Evidence from Sweden. J. Popul. Econ. 28 (3), 659-695. http://doi.10.1007/s00148-015-0551-2 